\title{
Analisis hasil uji kompetensi guru matematika sekolah menengah pertama (SMP) di Kota Tasikmalaya
}

\author{
Redi Hermanto, Satya Santika \\ Program Studi Pendidikan Matematika, Fakultas Keguruan dan IImu Pendidikan, \\ Universitas Siliwangi, Tasikmalaya, Indonesia \\ E-mail: redihermanto@unsil.ac.id
}

\begin{abstract}
Certification of teachers that has lasted more than a decade aimed to produce professional teachers, thus impacting significantly to the advancement of education in Indonesia. But the reality in Tasikmalaya, West Java, it is very much different from the expectations. The majority of teachers are even more concerned in the increasement of social status than the professional quality as an educator. More recently the government has implemented Teacher Competency Test (UKG), which was held simultaneously throughout Indonesia with the aim to determine the ability of teachers' pedagogical and professional competences. The purpose of this study was to determine the mapping of the teachers' competency by rank, domain competence, academic qualification, age, gender, and see the difference in results UKG based certification status. Outputs resulting from this study were (1) to map the results UKG mathematics of junior high school in Tasikmalaya, (2) to formulate recommendations or proposals regarding the improvement of the UKG (3) to formulate recommendations or proposals of sustainable planning of professional development for teachers. The method used in this research were study documentation, interviews and questionnaires open. The mapping of UKG results can be used as consideration in evaluating the program especially in what improvements need to be prioritized. By using the techniques of interviews and open questionnaire, was expected collect information of the effect of UKG for the teachers.
\end{abstract}

Keywords: Certification of teachers, Teacher Competency Test, UKG

\section{PENDAHULUAN}

Undang-undang Republik Indonesia Nomor 20 Tahun 2003 tentang Sistem Pendidikan Nasional menyatakan bahwa jabatan guru sebagai pendidik merupakan jabatan profesional. Undang-Undang Nomor 14 Tahun 2005 tentang Guru dan Dosen mengamanatkan bahwa guru adalah pendidik profesional dengan tugas utama mendidik, mengajar, membimbing, mengarahkan, melatih, menilai, dan mengevaluasi peserta didik pada pendidikan anak usia dini jalur pendidikan formal, pendidikan dasar, dan pendidikan menengah. Untuk itu, profesionalisme guru dituntut terus berkembang sesuai dengan perkembangan zaman, perkembangan ilmu pengetahuan dan teknologi, serta kebutuhan masyarakat.

Dalam upaya untuk meningkatkan profesionalisme guru, diperlukan adanya peta yang menggambarkan penguasaan kompetensi dari masing-masing guru. Berpijak dari peta tersebut, akan dikembangkan pelatihan peningkatan profesionalisme guru yang sesuai dengan apa yang dibutuhkan oleh masing-masing guru. Oleh karena itu, Kementerian Pendidikan dan Kebudayaan perlu melakukan pengukuran profesionalisme guru, yaitu dengan Uji Kompetensi Guru (UKG).

UKG secara rutin telah dilakukan sejak tahun 2012 bagi guru yang akan mengikuti sertifikasi guru. Mulai tahun 2015 ini UKG secara rutin akan dilakukan untuk mengukur profesionalisme guru. Tujuannya untuk mengetahui level kompetensi individu guru dan peta penguasaan guru pada kompetensi pedagogik dan kompetensi profesional. Pelaksanaan UKG difokuskan pada identifikasi kelemahan guru dalam penguasaan kompetensi pedagogik dan profesional. UKG tahun 2015 dilakukan secara sensus atau diikuti oleh semua guru dalam jabatan, 
baik guru PNS maupun bukan PNS dengan jumlah jenis soal yang diujikan adalah 200 mata pelajaran/guru kelas/paket keahlian/BK. Perolehan hasil UKG pada masing-masing guru menjadi bagian dari penilaian kinerja guru, oleh karena itu sesuai dengan prinsip profesional guru akan mengikuti UKG pada mata pelajaran sesuai dengan sertifikat pendidik dan jenjang pendidikan yang diampunya. Disamping itu, hasil UKG juga digunakan sebagai bahan pertimbangan kebijakan dalam pemberian program pembinaan dan pengembangan profesi guru serta pemberian penghargaan dan apresiasi kepada guru.

UKG tahun 2015 disiapkan dengan proses yang terbuka, sesuai dengan prinsip-prinsip evaluasi, adil, terbuka, jujur, dan akuntabel dengan melibatkan para ahli sesuai dengan bidangnya serta publik, sehingga diyakini kredibel. UKG dilaksanakan secara periodik sehingga dapat mengukur perkembangan kompetensi guru dari waktu ke waktu. Oleh karena itu, diperlukan keterlibatan publik dalam penyempurnaan pelaksanaan UKG dan perancangan program pembinaan guru pasca UKG. Salah satu upaya yang dilakukan adalah dengan memberikan kesempatan kepada publik untuk melakukan kajian terhadap pengembangan kompetensi guru pasca UKG dengan memanfaatkan data hasil UKG. Hasil penelitian tersebut diharapkan akan memberikan masukan-masukan yang positif dalam memperbaiki kualitas kompetensi guru yang akan datang.

Untuk menjadi seorang guru yang profesional, diperlukan perjuangan yang tidak mudah. Oleh karena itu, kebijakan pembinaan dan pengembangan profesi guru harus dilakukan secara kontinu. Pengembangan profesi guru idealnya diawali dengan penyiapan calon guru, rekruitmen, penempatan, penugasan, pengembangan profesi dan karir, hingga menjadi guru profesional sejati, yang menjalani profesionalisasi secara terus-menerus. Pengembangan keprofesian guru salah satunya diawali melalui Uji Kompetensi Guru (UKG). Atas dasar itu dapat dirumuskan profil dan peta kompetensinya. Kondisi nyata itulah yang menjadi salah satu dasar peningkatan kompetensi guru. Dengan demikian, hasil penilaian Uji Kompetensi Guru (UKG) menjadi salah satu basis utama desain program peningkatan kompetensi guru. Selanjutnya, guru-guru pun perlu diketahui tingkat kompetensinya melalui uji kompetensi. Uji kompetensi dimaksudkan untuk memperoleh informasi tentang kondisi nyata guru dalam proses pendidikan dan pembelajaran. Dengan demikian, tujuan uji kompetensi adalah menilai dan menetapkan apakah guru sudah kompeten atau belum dilihat dari standar kompetensi yang diujikan.

Berdasarkan uraian di atas, tentunya Uji Kompetensi Guru (UKG) wajib diikuti oleh guru PNS maupun NON PNS baik guru yang sudah tersertifikasi maupun yang belum tersertifikasi. Guru yang sudah tersertifikasi adalah guru yang sudah memperoleh sertifikat pendidik dari pemerintah, dan berhak mendapatkan tunjangan profesi. Sementara guru-guru yang belum tersertifikasi, seolah-olah dianggap sebagai guru yang belum profesional. Padahal, mendapat tunjangan profesi atau tidak, guru harus tetap bekerja secara profesional. Hal tersebut kemudian mengakibatkan terjadinya kesenjangan dan hubungan yang kurang sehat antar guru yang sudah tersertifikasi dan yang belum tersertifikasi, sehingga bisa menjadi kendala bagi guru dalam melaksanakan tugasnya.

Hal ini yang mendorong penulis untuk melakukan sebuah studi, sehingga hasil dari studi ini dapat memberikan gambaran mengenai kemampuan kompetensi guru dan mampu memberikan sumbangsih pemikiran dalam menyikapi hasil dari Uji Kompetensi Guru (UKG) yang telah dilaksanakan dalam beberapa bulan terakhir ini. Agar pemasalahan yang dikaji tidak terlalu luas, maka studi ini dibatasi hanya mengkaji tentang hasil Uji Kompetensi Guru (UKG) matematika SMP yang ada di Kota Tasikmalaya, sehingga rumusan masalah yang akan di kaji dalam studi ini adalah sebagai berikut: (1) Bagaimanakah peta kompetensi guru matematika SMP di Kota Tasikmalaya secara keseluruhan ditinjau berdasarkan 
kepangkatan, ranah kompetensi, kualifikasi akademik, usia, dan jenis kelamin?; (2) Apakah ada perbedaan antara kompetensi guru matematika SMP di Kota Tasikmalaya berdasarkan status sertifikasinya?

Studi ini dilakukan guna melengkapi data Uji Kompetensi Guru Matematika SMP di Kota Tasikmalaya sehingga dapat menggambarkan kompetensi guru secara utuh di lapangan. Studi ini diharapkan dapat memberikan gambaran pemetaan kompetensi guru matematika SMP yang dapat dijadikan sebagai bahan pertimbangan dalam penetapan kebijakan dan tindak lanjut dalam upaya peningkatan kompetensi guru. Luaran yang dihasilkan dari studi ini adalah untuk memberikan gambaran terkait dengan hasil Uji Kompetensi Guru (UKG) matematika SMP di Kota Tasikmalaya yang nantinya akan berdampak pada pada terlaksananya program pemetaan kompetensi guru, pembinaan kompetensi dan profesionalitas guru. Disamping itu, luaran pelaksanaan studi ini adalah untuk memberikan rekomendasi terkait dengan perbaikan pelaksanaan UKG pada tahun-tahun berikutnya.

Kualifikasi dan kompetesi seorang guru menjadi satu syarat penting untuk menunjukkan bahwa pekerjaan profesional memiliki dasar keilmuan dan teori tertentu.Kualifikasi akademik diperoleh melalui proses pendidikan yang cukup lama dan dilakukan dengan seleksi secara terus menerus. Oleh karena itu seorang guru profesional harus dapat diuji kemampuan teknisnya yang berkaitan dengan kemampuan pedagogis, profesional, komunikasi, kepribadian dan sosial. Dalam UU No. 14 tahun 2005 tentang guru dan dosen menyatakan bahwa, kualifikasi akademik ini harus dibuktikan melalui penguasaan guru terhadap empat kompetensi utama, yaitu kompetensi pedagogik, kompetensi profesional, kompetensi kepribadian dan kompetensi sosial.

Kompetensi adalah kemampuan yang dimiliki seseorang akibat dari pendidikan maupun pelatihan, atau pengalaman belajar informal tertentu yang didapat, sehingga menyebabkan seseorang dapat melaksanakan tugas tertentu dengan memuaskan (Payong, 2011:17). Sedangkan menurut Usman kompetensi adalah suatu hal yang menggambarkan kualifikasi atau kemampuan seseorang, baik yangkualitatif maupun kuantitaif (Kunandar, 2007:5152). Pengertian ini mengandung makna bahwa kompetensi itu dapat digunakan dalam dua konteks yaitu pertama, sebagai indikator kemampuan yang menunjukkan kepada perbuatan yang diamati, kedua, sebagai konsep yang mencakup aspek-aspek kognitif, afektif serta tahap-tahap pelaksanaannya secara utuh.

Uji Kompetensi Guru (UKG) dimaksudkan untuk mengetahui peta penguasaan guru pada kompetensi pedagogik dan profesional.Output uji kompetensi guru difokuskan pada identifikasi kelemahan guru dalam penguasaan kompetensi pedagogik dan profesional. Berdasarkan landasan hukum berkaitan dengan UKG, maka UKG wajib diikuti oleh semua guru dalam jabatan baik guru PNS maupun bukan PNS.

Bagi komunitas guru, baik PNS maupun non-PNS UKG adalah issue yang paling hangat dibicarakan akhir-akhir ini. Berbagai diskusi seputar UKG tidak hanya ramai di dunia nyata, namun juga menjadi trending topic di sosial media. Uji Kompetensi Guru (UKG) yang akan dilaksanakan secara nasional pada tanggal 9 - 25 Nopember 2015, yang untuk mengetahui level kompetensi individu guru dan peta penguasaan guru pada kompetensi pedagogik dan kompetensi profesional. Pelaksanaan UKG difokuskan pada identifikasi kelemahan guru dalam penguasaan kompetensi pedagogik dan profesional (Kemdikbud, 2015 : 3).

Menurut Pedoman Pelaksanaan UKG yang dikeluarkan Kemdikbud, ada beberapa landasan teoritik pedagogis yang melatar belakangi pelaksanaan UKG, yaitu (1) UKG adalah penilaian terhadap kompetensi guru sebagai bagian penilaian kinerja guru dalam rangka pembinaan 
karir kepangkatan dan jabatannya; (2) Pembinaan dan pengembangan profesi guru hanya dapat dilakukan secara efektif jika berbasis pada pemetaan kompetensi guru; (3) Uji kompetensi guru berfungsi sebagai pemetaan kompetensi guru (kompetensi pedagogik dan profesional); (4) Untuk membangun eksistensi dan martabat sebuah profesi diperlukan mutu atau kualitas para anggota yang tergabung dalam profesi tersebut; (5) Ukuran kinerja dapat dilihat dari kualitas hasil kerja, ketepatan waktu menyelesaikan pekerjaan, prakarsa dalam menyelesaikan pekerjaan, kemampuan menyelesaikan pekerjaan, dan kemampuan membina kerjasama dengan pihak lain.

UKG sejatinya adalah dalam rangka meningkatkan kualitas pendidikan di Indonesia. Salah satu faktor utama dalam dunia pendidikan adalah tersedianya guru yang profesional dan kompeten (Dirjen GTK, 2015: www.tempo.co). Tujuan pelaksanaan UKG adalah untuk: (1) Memperoleh informasi tentang gambaran kompetensi guru, khususnya kompetensi pedagogik dan profesional sesuai dengan standar yang telah ditetapkan; (2) Mendapatkan peta kompetensi guru yang akan menjadi bahan pertimbangan dalam menentukan jenis pendidikan dan pelatihan yang harus diikuti oleh guru dalam program pembinaan dan pengembangan profesi guru dalam bentuk kegiatan pengembangan keprofesian berkelanjutan (PKB); (3) Memperoleh hasil UKG yang merupakan bagian dari penilaian kinerja guru dan akan menjadi bahan pertimbangan penyusunan kebijakan dalam memberikan penghargaan dan apresiasi kepada guru (Kemdikbud, 2015 : 13).

\section{METODE PENELITIAN}

Metode yang digunakan penelitian ini adalah metode kuantitatif deskriptif. Penelitian diarahkan untuk mengetahui apakah antara dua atau lebih dari dua kelompokada perbedaan dalam aspek atau variabel yang diteliti. Dalam penelitian ini pun tidak ada pengontrolan variabel, maupun manipulasi/perlakuan dari peneliti (McMillan dan Schumacher, 2001). Penelitian ini dilakukan melalui studi dokumentasi. Hasilnya dianalisis secara statistik untuk mencari perbedaan di antara variabel-variabel yang diteliti. Populasi dalam kajian ini adalah guru matematika SMP di Kota Tasikmalaya sebanyak 190 orang. Data hasil UKG matematika SMP diambil dari pusat data dan untuk mempertajam hasil analisis, peneliti mengundang 25 orang guru matematika SMP di Kota Tasikmalaya untuk mengisi angket terbuka dan wawancara.

Rincian rencana kegiatan penelitian dilakukan melalui beberapa tahapan. Pada tahap pertama dilakukan pengkajian tentang hasil Uji Kompetensi Guru (UKG) yang diteliti yaitu kompetensi profesional, pedagogik, serta profesional dan pedagogik yang datanya sudah terdokumentasikan di pusat data GTK. Tahap kedua, untuk mempertajam hasil analisis, peneliti menyusun sebuah instrumen berupa angket terbuka untuk diisi oleh guru dan melakukan wawancara terkait segala sesuatu yang berhubungan dengan persiapan, pelaksanaan, evaluasi serta harapan guru terkait dengan UKG yang telah dilaksanakan. Tahap selanjutnya adalah pengolahan dan analisis data hasil studi yang telah dilakukan.

\section{HASIL DAN PEMBAHASAN}

Berdasarkan peta kompetensi guru matematika SMP secara keseluruhan di kota Tasikmalaya, tampak bahwa rerata hasil UKG yang diperoleh melebihi standar UKG yang ditetapkan untuk tahun 2015 yaitu 55. Baik kompetensi pedagogik maupun kompetensi profesional ataupun keduanya sekaligus telah melebihi 55. Meskipun demikian, jika dilihat dari nilai 
minimum yang diperoleh baik pada kompetensi pedagogik maupun kompetensi profesional masih ada nilai UKG yang jauh di bawah standar UKG. Oleh karena masih ada nilai UKG yang masih jauh di bawah standar UKG yang ditetapkan, ini artinya kompetensi pedagogik dan profesional masih dapat dan perlu ditingkatkan bagi guru matematika SMP.

Berdasarkan peta kompetensi guru menurut kepangkatannya, guru matematika SMP di Kota Tasikmalaya dengan golongan III/b memperoleh rerata UKG paling rendah pada kompetensi pedagogik dibanding golongan lainnya. Berbeda dengan rerata kompetensi pedagogiknya, rerata kompetensi profesional justru terlihat setara dengan golongan lainnya. Meskipun demikian, rerata secara keseluruhan (pedagogik + profesional) untuk golongan III/b jelas masih paling bawah dibanding golongan lainnya. Oleh karena itu bila ada peluang pelatihan yang terkait dengan kompetensi pedagogik seharusnya memprioritaskan golongan III/b sebagai sasaran pertama.

Peta kompetensi guru matematika SMP di Kota Tasikmalaya menurut ranah kompetensinya menunjukkan bahwa secara rata-rata, kompetensi pedagogik memiliki rata-rata hasil UKG lebih rendah dibandingkan kompetensi profesional. Hal ini dimungkinkan sebagian besar guru matematika SMP di Kota Tasikmalaya telah mengikuti program sertifikasi guru sehingga kompetensi profesionalnya lebih terasah. Oleh karena itu bila ada peluang pelatihan guru seharusnya memprioritaskan pelatihan untuk mengasah kompetensi pedagogik.

Berdasarkan peta kompetensi guru matematika SMP di Kota Tasikmalaya menurut kualifikasi akademiknya, tampak bahwa rerata kompetensi pedagogik yang dianggap rendah yaitu pada kualifikasi akademik <= SMA, D1, dan D2. Sedangkan rerata kompetensi profesional nampak lebih rendah pada kualifikasi akademik D2 dan D3. Oleh karena itu bila ada peluang pelatihan kompetensi pedagogik dan profesional seharusnya dapat memprioritaskan guru dengan kualifikasi <= SMA, D1 dan D2.

Peta kompetensi guru matematika SMP di Kota Tasikmalaya menurut usia menunjukkan bahwa rerata kompetensi pedagogik tampak lebih rendah pada rentang usia 21-30 dan 5160, kemudian rentang 41-50 dan rentang 31-40. Sedangkan rerata kompetensi profesional tampak lebih rendah pada rentang 21-30, kemudian semakin naik rentang umurnya maka rerata kompetensi profesionalnya semakin tinggi. Oleh karena itu apabila ada peluang pelatihan kompetensi pedagogik seharusnya diprioritaskan guru matematika dengan rentang usia 21-30 dan 51-60 tahun, dan bila ada peluang pelatihan kompetensi profesional seharusnya diprioritaskan guru matematika dengan rentang usia 21-30.

Berdasarkan kompetensi guru matematika SMP di Kota Tasikmalaya menurut jenis kelamin nampak bahwa rerata kompetensi pedagogik dan profesional untuk laki-laki lebih rendah dibandingkan perempuan. Sehingga bila ada peluang pelatihan kompetensi pedagogik dan profesional dapat memprioritaskan guru laki-laki.

Hasil analisis perbedaan kompetensi pedagodik guru matematika SMP di Kota Tasikmalaya berdasarkan status sertifikasinya, diperoleh bahwa tidak terdapat perbedaan yang signifikan untuk hasil UKG pada kompetensi pedagogik antara guru yang sudah bersertifikat pendidik dengan guru yang belum disertifikasi. Hal ini logis jika selama masa kerjanya, baik guru yang sudah bersertifikat pendidik maupun yang belum disertifikasi telah mendapat dukungan untuk meningkatkan kompetensi pedagogiknya. Berbagai jenis buku sumber, tutorial, dan dukungan komunitas dapat mengasah kompetensi pedagogiknya tanpa harus terbatasi oleh status sertifikasi. 
Hasil analisis perbedaan kompetensi profesional guru matematika SMP di Kota Tasikmalaya berdasarkan status sertifikasinya, diperoleh bahwa terdapat perbedaan yang signifikan untuk hasil UKG pada kompetensi profesional antara guru yang sudah bersertifikat pendidik dengan guru yang belum disertifikasi. Hal ini logis jika guru yang bersertifikat pendidik telah menjalani pelatihan profesi guru dan dinyatakan sebagai guru profesional secara legal dengan kepemilikan sertifikat pendidik. Sedangkan bagi guru yang belum disertifikasi jelas belum menjalani pelatihan profesi guru sehingga dalam hal ini kalah secara pengalaman jika dibandingkan guru yang bersertifikat pendidik.

Hasil analisis perbedaan hasil UKG matematika SMP secara keseluruhan di Kota Tasikmalaya berdasarkan status sertifikasinya, diperoleh bahwa terdapat perbedaan yang signifikan untuk hasil UKG pada kompetensi pedagogik dan profesional sekaligus antara guru yang sudah bersertifikat pendidik dengan guru yang belum disertifikasi. Meskipun secara terpisah kompetensi pedagogik terlihat sama, namun secara akumulasi dengan kompetensi profesional menjadikan rerata hasil UKG untuk guru bersertifikat pendidik berbeda dengan guru yang belum disertifikasi.

Lebih jauh peneliti melakukan wawancara terhadap beberapa guru matematika SMP di Kota Tasikmalaya untuk memperoleh data tambahan mengenai pelaksanaan UKG. Hasilnya ditemukan beberapa kendala yang dihadapi. Kendala tersebut dapat dijadikan masukan untuk perbaikan dari kelemahan pada pelaksanaan UKG. Berdasarkan hasil wawancara mengenai hasil UKG kepada guru matematika SMP di Kota Tasikmalaya, berikut ini digambarkan kendala bagi guru matematika SMK pada pelaksanaan UKG: (1) Masih adanya gangguan teknis berupa matinya aliran listrik dan faktor keterlambatan komputer dalam merespon sistem UKG. Gangguan ini tidak dapat dipungkiri karena karakteristik perbedaan tempat. Namun bukan berarti perbedaan ini hanya cukup dianggap wajar, setidaknya ada upaya siap tanggap ketika gangguan ini muncul; (2) Jadwal pelaksanaan UKG ada yang masih berbenturan dengan jadwal kegiatan sekolah. Sehingga bagi guru yang kekurangan waktu pembelajaran bersama siswanya diharuskan mencari waktu tambahan lain sebagai ganti tersitanya pelaksanaan UKG; dan (3) Waktu yang disediakan untuk mengerjakan UKG masih terasa tidak cukup bagi sebagian guru. Hal ini tentu berkaitan dengan kesulitan soal UKG yang diberikan. Meskipun ini dipastikan faktor intern sebagian guru, namun hendaknya perlu ditindaklanjuti.

\section{SIMPULAN DAN SARAN}

Berdasarkan hasil analisis dan pembahasan dapat ditarik simpulan sebagai berkut: (1) Peta kompetensi guru menurut kepangkatannya, guru matematika SMP di Kota Tasikmalaya dengan golongan III/b memperoleh rerata nilai UKG paling rendah dibanding golongan lainnya; (2) Peta kompetensi guru matematika SMP di Kota Tasikmalaya menurut ranah kompetensinya menunjukkan bahwa kompetensi pedagogik memperoleh rata-rata hasil UKG lebih rendah dibandingkan kompetensi profesional; (3) Peta kompetensi guru menurut kualifikasi akademiknya, guru matematika SMP di Kota Tasikmalaya dengan kualifikasi akademik <= SMA, D1, dan D2 memperoleh nilai UKG lebih rendah dibanding kualifikasi akademik lainnya; (4) Peta kompetensi guru menurut usianya, guru matematika SMP di Kota Tasikmalaya pada rentang usia 21-30 memperoleh rerata hasil UKG lebih rendah dibanding rentang lainnya; (5) Peta kompetensi guru matematika SMP di Kota Tasikmalaya menurut jenis kelaminnya menunjukkan bahwa rerata hasil UKG untuk lakilaki lebih rendah dibandingkan perempuan; (6) Tidak terdapat perbedaan yang signifikan untuk hasil UKG pada kompetensi pedagogik antara guru yang sudah bersertifikat pendidik dengan guru yang belum disertifikasi; (7) Terdapat perbedaan yang signifikan untuk hasil 
UKG pada kompetensi profesional antara guru yang sudah bersertifikat pendidik dengan guru yang belum disertifikasi; dan (8) Terdapat perbedaan yang signifikan untuk hasil UKG pada kompetensi pedagogik dan profesional sekaligus antara guru yang sudah bersertifikat pendidik dengan guru yang belum disertifikasi.

Dari kesimpulan tersebut di atas, dapat disampaikan saran-saran sebagai berikut: (1) Jika dilihat dari nilai minimum yang diperoleh baik pada kompetensi pedagogik maupun kompetensi profesional masih ada nilai UKG yang jauh di bawah standar UKG tahun 2015. Oleh karena kompetensi pedagogik dan profesional masih dapat dan perlu ditingkatkan bagi guru matematika SMP di Kota Tasikmalaya; (2) Pelatihan yang terkait dengan kompetensi pedagogik seharusnya memprioritaskan golongan III/b dibandingkan golongan lainnya; (3) Pelatihan guru seharusnya memprioritaskan pelatihan pada kompetensi pedagogik dibandingkan kompetensi profesional; (4) Pelatihan kompetensi pedagogik dan profesional seharusnya memprioritaskan guru dengan kualifikasi <=SMA, D1 dan D2; (5) Pelatihan kompetensi pedagogik seharusnya diprioritaskan guru matematika dengan rentang usia 21-30 dan 51-60 tahun, dan pelatihan kompetensi profesional seharusnya diprioritaskan guru matematika dengan rentang usia 21-30; (6) Pelatihan kompetensi pedagogik dan profesional dapat memprioritaskan guru laki-laki; (7) Oleh karena adanya perbedaan ratarata hasil UKG antara guru matematika SMP yang bersertifikat pendidik dengan yang belum disertifikasi, maka diharapkan semua guru sudah bersertifikat pendidik; (8) Melihat adanya gangguan teknis yang terjadi saat pelaksanaan UKG, panitia diharapkan mempersiapkan langkah praktis dalam menanganinya; (9) Waktu pelaksanaan UKG hendaknya serempak dan kontinu; (10) soal-soal yang diberikan hendaknya dikaji untuk disesuaikan lagi dengan kepraktisan di lapangan dan waktu pengerjaannya dapat disesuaikan lagi; dan (11) Kelulusan UKG hendaknya diikuti dengan penghargaan tertentu agar guru lebih termotivasi.

\section{DAFTAR RUJUKAN}

Badan Standar Nasional Pendidikan. (2007). Standar Kualifikasi Akademik dan Kompetensi Guru. Jakarta: BSNP

Depdiknas. (2005). Undang-undang Republik Indonesia Nomor 14 Tahun 2005 tentang Guru dan Dosen. Jakarta: Depdiknas

. (2005). Peraturan Pemerintah Republik Indonesia Nomor 19 Tahun 2005 tentang Standar Nasional Pendidikan. Jakarta: Depdiknas

(2007). Peraturan Pemerintah Republik Indonesia Nomor 16 Tahun 2007 tentang Standar Kualifikasi Akademik dan Kompetensi Guru. Jakarta: Depdiknas

Ditjen Dikti Kemendiknas. (2015). Sertifikasi Guru dalam Jabatan, Buku 2 Petunjuk Teknis Pelaksanaan Sertifikasi Guru di Rayon LPTK. Jakarta: Dikti

(2015). Sertifikasi Guru dalam Jabatan, Buku 3 Pedoman Penyusunan Portofolio. Jakarta: Dikti

(2015). Sertifikasi Guru dalam Jabatan, Buku 4 Rambu-Rambu Pelaksanaan Pendidikan dan Pelatihan Profesi Guru. Jakarta: Dikti

Kunandar. (2007). Guru Profesional Implementasi KTSP dan Sukses Sertifikasi. Jakarta: Raja Grafindo Persada

Marcelus R Payong. (2011). Sertifikasi profesi guru (konsep dasar, problematika dan implementasinya). Jakarta: PT. Indeks

McMillan, J.H dan Schumacher, S. (2001). Research in Education: A Conceptual Intro-duction ( $5^{\text {th }}$ ed.), US, Longman.Inc. 
